\title{
Evaluation of safety and efficacy of Deferoxamine compared with deferasirox in transfusion dependent beta thalassemia patients: a single center
} retrospective study

\author{
Narjis Batool ${ }^{1 *}$, Sadia Yasmeen ${ }^{1}$, Rabia Anwar ${ }^{1}$, Zikria Saleem $^{1,2,3}$ \\ 1 Punjab University College of Pharmacy, University of the Punjab, Lahore, Pakistan \\ 2 School of Pharmaceutical Sciences, Universiti Sains Malaysia, Malaysia \\ 3 University of Lahore, Faculty of Pharmacy, Lahore, Pakistan
}

*Corresponding Author: Dr. Narjis Batool, Punjab University College of Pharmacy, University of the Punjab, Old Campus, Lahore54000, Pakistan, Mobile \#+92(0)3216962136, Email: Narjisbatool105@gmail.com

\section{Abstract}

Purpose: The primary cause of mortality and morbidity in thalassemia major is iron overload. The objective of this study was to compare the safety and efficacy of deferoxamine and deferasirox in transfusion dependent beta thalassemia patients. Methods: A retrospective observational study was conducted among 178 patients. Patients were divided into two groups, deferoxamine group (90 patients) and deferasirox group (88 patients). Standardized data collection form was used to collect data. Clinical and demographic characteristics of patients were recorded by checking medical records. The collected data was analyzed using SPSS software. Findings: It was revealed that both drugs, deferoxamine and deferasirox were effective and safe in transfusion dependent beta thalassemic patients. Both are efficacious in reducing serum ferritin level. Their laboratory parameters were within clinically accepted range. Conclusion: Deferoxamine and deferasirox treatment have equal efficacy and safety for transfusion dependent beta thalassemia population. Therefore, oral deferasirox is recommended for more compliance and convenience.

Keywords: Iron chelators; Iron overload; Thalassemia; Safety; Efficacy.

\section{INTRODUCTION}

Thalassemia is a genetic blood disorder, caused by mutation in globin chains (alpha and beta) of hemoglobin [1]. Globally, approximately $7 \%$ population has defected hemoglobin gene and about $300000-500000$ babies are carrier of haemoglobinopathies ( $\beta$-thalassemia, $\alpha$-thalassemia, and sickle cell disease) ${ }^{[2]}$. Around 5000 children are born with beta $(\beta)$ thalassemia every year in Pakistan with $5-8 \%$ carrier rate ${ }^{[3}$. Such people requires frequent blood transfusion which resulted in accumulation of iron with subsequent organ damage and death $[4,5]$. Patients with iron overload need iron chelation therapy for improvement with iron chelators (deferiprone, deferasirox, or deferoxamine) ${ }^{[6,7]}$.

Deferoxamine (DFO), a naturally occurring trihydroxamic acid produced by Streptomyces pilosus, is an iron chelating agent administered as intramuscularly ${ }^{[8]}$, intravenously [9] or subcutaneously ${ }^{[10]}$ and considered as standard therapy for iron overload worldwide in patients with transfusion dependent $\beta$ thalassemia [11,12]. But DFO treatment over 8 to 12 hours daily is a burdensome regimen and can leads to poor compliance, reduced efficacy, bad quality of life and some other risks like skin rash and heart failure [13-16].

Deferasirox (DFX) is an oral iron chelating agent with efficacy, tolerability and safety in preventing iron accumulation due to blood transfusion in patients (above 2 years) with $\beta$ thalassemia major [17]. Preclinical and clinical data has demonstrated its positive effect in reducing liver and cardiac iron ${ }^{[18-20]}$. However, a study indicated that it causes transient acute renal insufficiency [21].

There is limited research in Pakistan high lightening the comparison between DFO and DFX in terms of safety and 
efficacy. Therefore, this study was conducted to compare the safety and effectiveness of DFO and DFX in patients with blood transfusion-dependent $\beta$-thalassemia major.

\section{METHODS}

A retrospective observational study was conducted over a 6month period among children and adolescents with Thalassemia. The ethical approval for the study was granted by review board on human research of University College of Pharmacy, Punjab University Lahore, Pakistan. Participants in the study were selected based on the inclusion and exclusion criteria. Sample size was calculated using Cochran formula for prevalence ${ }^{[22]}$.

Patients, aged 5 years and above, diagnosed with $\beta$ thalassemia major with current serum ferritin higher than 1000 $\mathrm{ng} / \mathrm{ml}$ were included as well as patients with a lifetime history of at least 20 units of red cell transfusions and received at least $\geq 10$ units/year of red blood cells transfusions. Patients were excluded if they were participating in any clinical trial or receiving an investigational drug. Those patients who were suffering from co-morbid clinical conditions were also excluded. Standardized data collection form was used to collect data from 178 patients. Patients were divided into two groups (DFO and DFX group). We recorded basic demographics (e.g., gender, age, payment, etc.), and clinical information (e.g., diagnosis, $\mathrm{Hb}$ level, complications, serum ferritin level, iron chelation treatment etc.) of patients in a clinical record form. Efficacy of the chelation was assessed by change in serum ferritin. Safety was evaluated by clinical and laboratory monitoring of adverse effects, including complete blood count, serum creatinine and blood urea. Gastrointestinal disorders (nausea, vomiting, diarrhea and abdominal pain,), local skin reactions (hardness, swelling, redness, and soreness), and other symptoms were also checked. Six cycles of treatment were evaluated and compared.

All the data collected was analyzed by using SPSS (Statistical Package for the Social Sciences) program. $\mathrm{P}<0.05$ was considered as statistically significant.

\section{RESULTS}

Demographics characteristics of all Patients are presented in the Table 1. Data of 178 patient's was analyzed. 90 patients were taking DFO as iron chelating agent whereas DFX was given to 88 patients for iron overload treatment. Majority of the patients getting DFO and DFX treatment were male and resident of rural area. It was found that $98.3 \%$ were dependent on guardians and belonged to very low socioeconomic class with monthly income less than 20,000 PKR. More than half (56.7) of the participants have family history of thalassemia.

Table 1: Demographics characteristics of study population

\begin{tabular}{|l|l|l|l|l|l|}
\hline Parameters & Deferoxamine N (\%) & Deferasirox N (\%) & Total N (\%) & P-value \\
\hline \multirow{3}{*}{ Gender } & Male & $55(61.1)$ & $60(68.2)$ & $115(64.6)$ & 0.350 \\
\cline { 2 - 5 } & Female & $35(38.9)$ & $28(31.8)$ & $63(35.4)$ & \\
\hline Locality & Rural & $49(54.4)$ & $65(73.9)$ & $114(64.0)$ & \multirow{2}{*}{0.008} \\
\cline { 2 - 5 } & Urban & $41(45.6)$ & $23(26.1)$ & $64(36.0)$ & \\
\hline \multirow{2}{*}{ Income source } & Self & $0(0.0)$ & $4(4.5)$ & $4(2.2)$ & \multirow{2}{*}{0.121} \\
\cline { 2 - 5 } & Dependent & $89(100)$ & $85(96.6)$ & $174(98.3)$ & \\
\hline Family history income & $<20 \mathrm{~K}$ & $87(97.8)$ & $84(95.5)$ & $171(96.6)$ & \multirow{2}{*}{0.444} \\
\cline { 2 - 5 } & $>20 \mathrm{~K}$ & $3(3.3)$ & $4(4.5)$ & $7(3.9)$ & \\
\cline { 2 - 5 } & Yes & $52(57.8)$ & $49(55.7)$ & $101(56.7)$ & \multirow{2}{*}{0.880} \\
\cline { 2 - 5 } & No & $38(42.2)$ & $39(44.3)$ & $77(43.3)$ & \\
\hline
\end{tabular}

Table 2: Comparison of lab values of treatment groups (DFO and DFX)

\begin{tabular}{|c|c|c|c|c|c|c|c|c|c|c|c|c|}
\hline \multirow[t]{2}{*}{ Lab Values } & \multicolumn{6}{|c|}{ Deferoxamine } & \multicolumn{6}{|c|}{ Deferasirox } \\
\hline & Cycle 1 & Cycle 2 & Cycle 3 & Cycle 4 & Cycle 5 & Cycle 6 & Cycle 1 & Cycle 2 & Cycle 3 & Cycle 4 & Cycle 5 & Cycle 6 \\
\hline Serum ferritin(ng/ml) & $\begin{array}{l}3949.53 \pm 2 \\
412.608\end{array}$ & $\begin{array}{l}4894.27 \pm 2 \\
665.128^{*}\end{array}$ & $\begin{array}{l}5984.59 \\
\pm 2627.5 \\
81\end{array}$ & $\begin{array}{l}7462 . \\
47 \pm 8 \\
446.2 \\
37\end{array}$ & $\begin{array}{l}6504 . \\
61 \pm 5 \\
443.3 \\
66\end{array}$ & $\begin{array}{l}5570 \\
.57 \pm \\
2591 \\
.836\end{array}$ & \begin{tabular}{|l|}
4432 \\
$.37 \pm 1$ \\
864.7 \\
23
\end{tabular} & $\begin{array}{l}6551 \\
.22 \pm \\
3957 \\
.098 \\
*\end{array}$ & $\begin{array}{l}5976 \\
.19 \pm \\
2946 \\
.356\end{array}$ & $\begin{array}{l}5722 \\
.10 \pm \\
3075 \\
.170\end{array}$ & $\begin{array}{l}6259 \\
.33 \pm \\
6570 \\
.789\end{array}$ & $\begin{array}{l}5987 \\
.48 \pm \\
3516 \\
.486\end{array}$ \\
\hline WBC's(10^3/ul) & $\begin{array}{l}15.72 \pm 13.0 \\
89\end{array}$ & $\begin{array}{l}10.93 \pm 10 \\
209\end{array}$ & $\begin{array}{l}11.26 \pm 9 \\
.277\end{array}$ & $\begin{array}{l}9.19 \pm \\
6.684\end{array}$ & $\begin{array}{l}10.90 \\
\pm 11.1 \\
93\end{array}$ & $\begin{array}{l}10.2 \\
2 \pm 6 . \\
048\end{array}$ & $\begin{array}{l}13.10 \\
\pm 17.2 \\
08\end{array}$ & $\begin{array}{l}9.60 \\
\pm 8.2 \\
54\end{array}$ & $\begin{array}{l}11.4 \\
5 \pm 12 \\
.626\end{array}$ & $\begin{array}{l}10.0 \\
0 \pm 7 . \\
372\end{array}$ & $\begin{array}{l}11.7 \\
5 \pm 13 \\
.307\end{array}$ & $\begin{array}{l}9.55 \\
\pm 5.0 \\
19\end{array}$ \\
\hline RBC's(10^6/ul) & $3.60 \pm 0.645$ & $\begin{array}{l}3.66 \pm 4.36 \\
1\end{array}$ & $\begin{array}{l}3.11 \pm 0 \\
.654\end{array}$ & $\begin{array}{l}3.34 \pm \\
1.126\end{array}$ & $\begin{array}{l}5.51 \pm \\
19.69 \\
5\end{array}$ & $\begin{array}{l}16.2 \\
1 \pm 62 \\
.981\end{array}$ & $\begin{array}{l}3.60 \\
\pm 1.7 \\
53\end{array}$ & $\begin{array}{l}3.06 \\
\pm 0.6 \\
42\end{array}$ & $\begin{array}{l}3.05 \\
\pm 0.8 \\
06\end{array}$ & $\begin{array}{l}3.42 \\
\pm 0.8 \\
41\end{array}$ & $\begin{array}{l}3.31 \\
\pm 0.6 \\
12\end{array}$ & $\begin{array}{l}3.20 \\
\pm 0.5 \\
24\end{array}$ \\
\hline
\end{tabular}




\begin{tabular}{|c|c|c|c|c|c|c|c|c|c|c|c|c|}
\hline Platelets(10^3/ul) & \begin{tabular}{|l|}
$381.14 \pm 173$ \\
.380
\end{tabular} & \begin{tabular}{|l|}
$257.63 \pm 15$ \\
3.404
\end{tabular} & \begin{tabular}{|l|}
$264.47 \pm$ \\
142.504
\end{tabular} & \begin{tabular}{|l|}
308.5 \\
$9 \pm 37$ \\
9.770
\end{tabular} & $\begin{array}{l}261.6 \\
1 \pm 13 \\
8.044\end{array}$ & \begin{tabular}{|l}
333. \\
$54 \pm 3$ \\
64.4 \\
37
\end{tabular} & $\begin{array}{l}312.2 \\
4 \pm 27 \\
0.77 \\
9\end{array}$ & \begin{tabular}{|l}
288. \\
$78 \pm$ \\
170. \\
961
\end{tabular} & \begin{tabular}{|l}
253. \\
$33 \pm 1$ \\
21.0 \\
89
\end{tabular} & $\begin{array}{l}286 . \\
70 \pm 1 \\
44.4 \\
36\end{array}$ & $\begin{array}{l}252 . \\
01 \pm 1 \\
19.1 \\
12\end{array}$ & $\begin{array}{l}271 . \\
01 \pm 1 \\
73.0 \\
57\end{array}$ \\
\hline LFT(ALT) & $\begin{array}{l}113.23 \pm 53 \\
148\end{array}$ & \begin{tabular}{|l|}
$106.14 \pm 69$ \\
$.762^{\star \star}$
\end{tabular} & $\begin{array}{l}74.53 \pm \\
41.872\end{array}$ & $\begin{array}{l}65.21 \\
\pm 47.9 \\
99\end{array}$ & $\begin{array}{l}74.0 \\
9 \pm 45 \\
.543\end{array}$ & $\begin{array}{l}67.5 \\
6 \pm 44 \\
.082\end{array}$ & $\begin{array}{l}116 . \\
39 \pm \\
69.30 \\
2\end{array}$ & \begin{tabular}{|l|}
71.2 \\
$2 \pm 5$ \\
0.52 \\
$8^{* *}$
\end{tabular} & $\begin{array}{l}80.7 \\
7 \pm 54 \\
.413\end{array}$ & $\begin{array}{l}80.1 \\
6 \pm 49 \\
.493\end{array}$ & \begin{tabular}{|l}
62.3 \\
$7 \pm 47$ \\
.477
\end{tabular} & $\begin{array}{l}61.8 \\
1 \pm 39 \\
.110\end{array}$ \\
\hline LFT(AST) & $\begin{array}{l}120.57 \pm 112 \\
.343\end{array}$ & \begin{tabular}{|l|}
$102.72 \pm 62$ \\
$.792^{* *}$
\end{tabular} & $\begin{array}{l}71.25 \pm \\
44.385\end{array}$ & $\begin{array}{l}59.33 \\
\pm 41.5 \\
07\end{array}$ & $\begin{array}{l}75.40 \\
\pm 62.1 \\
11\end{array}$ & $\begin{array}{l}75.1 \\
3 \pm 42 \\
.015\end{array}$ & $\begin{array}{l}82.0 \\
6 \pm 51 . \\
049\end{array}$ & \begin{tabular}{|l|}
62.4 \\
$1 \pm 3$ \\
8.20 \\
$8^{\star *}$ \\
\end{tabular} & $\begin{array}{l}74.9 \\
7 \pm 4 \\
6.87 \\
7 \\
\end{array}$ & $\begin{array}{l}66.4 \\
2 \pm 28 \\
.215\end{array}$ & $\begin{array}{l}52.6 \\
2 \pm 27 \\
.867\end{array}$ & $\begin{array}{l}76.5 \\
4 \pm 4 \\
3.61 \\
0 \\
\end{array}$ \\
\hline LFT(ALP) & $\begin{array}{l}333.18 \pm 176 \\
.546\end{array}$ & \begin{tabular}{|l|}
$320.00 \pm 15$ \\
1.744
\end{tabular} & $\begin{array}{l}397.93 \pm \\
153.82 \\
6\end{array}$ & $\begin{array}{l}384.3 \\
9 \pm 16 \\
5.447\end{array}$ & $\begin{array}{l}366 . \\
32 \pm 1 \\
59.21 \\
0\end{array}$ & $\begin{array}{l}344 . \\
00 \pm 1 \\
57.4 \\
43\end{array}$ & $\begin{array}{l}370.0 \\
3 \pm 15 \\
5.829\end{array}$ & \begin{tabular}{|l|}
351. \\
$02 \pm 1$ \\
59.1 \\
97 \\
\end{tabular} & $\begin{array}{l}380 . \\
03 \pm 1 \\
68.9 \\
36\end{array}$ & $\begin{array}{l}405 . \\
14 \pm 1 \\
33.3 \\
93\end{array}$ & \begin{tabular}{|l}
347. \\
$85 \pm 1$ \\
53.4 \\
45 \\
\end{tabular} & $\begin{array}{l}447 . \\
00 \pm 2 \\
8706 \\
6\end{array}$ \\
\hline RFT(Urea) & $\begin{array}{l}30.25 \pm 9.91 \\
5^{*}\end{array}$ & \begin{tabular}{|l|}
$26.87 \pm 9.7$ \\
09
\end{tabular} & $\begin{array}{l}26.76 \pm 6 \\
.888\end{array}$ & $\begin{array}{l}32.40 \\
\pm 6.84 \\
0\end{array}$ & $\begin{array}{l}21.8 \\
3 \pm 6.0 \\
90^{* *}\end{array}$ & $\begin{array}{l}23.4 \\
7 \pm 14 \\
.237\end{array}$ & $\begin{array}{l}24.73 \\
\pm 9.60 \\
9^{*}\end{array}$ & \begin{tabular}{|l|}
27.4 \\
$6 \pm 11$ \\
.017
\end{tabular} & $\begin{array}{l}24.7 \\
0 \pm 6 . \\
812\end{array}$ & $\begin{array}{l}29.9 \\
0 \pm 14 \\
.956\end{array}$ & $\begin{array}{l}28.1 \\
5 \pm 4 . \\
120^{* *}\end{array}$ & $\begin{array}{l}31.8 \\
3 \pm 11 \\
.325\end{array}$ \\
\hline RFT(Creatinine) & $2.42 \pm 8.138$ & $\begin{array}{l}0.52 \pm 0.35 \\
5\end{array}$ & $\begin{array}{l}0.52 \pm 0 . \\
361\end{array}$ & \begin{tabular}{|l|}
0.43 \\
\pm 0.12 \\
4
\end{tabular} & $\begin{array}{l}0.41 \pm \\
0.193\end{array}$ & $\begin{array}{l}0.58 \\
\pm 0.3 \\
44\end{array}$ & \begin{tabular}{|l|}
0.51 \\
\pm 0.2 \\
28
\end{tabular} & \begin{tabular}{|l|}
0.52 \\
\pm 0.2 \\
46
\end{tabular} & $\begin{array}{l}0.46 \\
\pm 0.2 \\
21\end{array}$ & $\begin{array}{l}0.48 \\
\pm 0.2 \\
17\end{array}$ & $\begin{array}{l}0.46 \\
\pm 0.2 \\
06\end{array}$ & \begin{tabular}{|l}
0.52 \\
\pm 0.3 \\
17
\end{tabular} \\
\hline
\end{tabular}

Table 2 represents the comparison of clinical values of six cycles of treatment with DFO and DFX. Serum ferritin level in DFO group increased significantly but dropped at last cycles. On the other hand, DFX treatment showed fluctuation in serum ferritin level. White blood cells, Platelets, Alanine aminotransferase (ALT) and Aspartate aminotransferase (AST) values decreased in both DFO and DFX group with the passage of time. However, alkaline phosphatase (ALP) and creatinine increased in both treatment groups. Red blood cells count elevated with DFO treatment while declined with DFX. Urea level decreased by DFO in each cycle while increased by DFX. The graphical presentation of comparison of two groups (DFO and DFX) is shown in Fig 1.

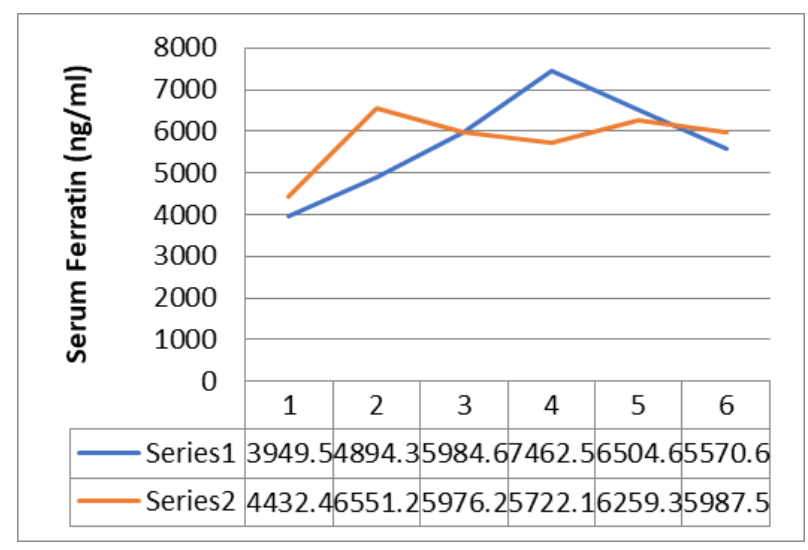

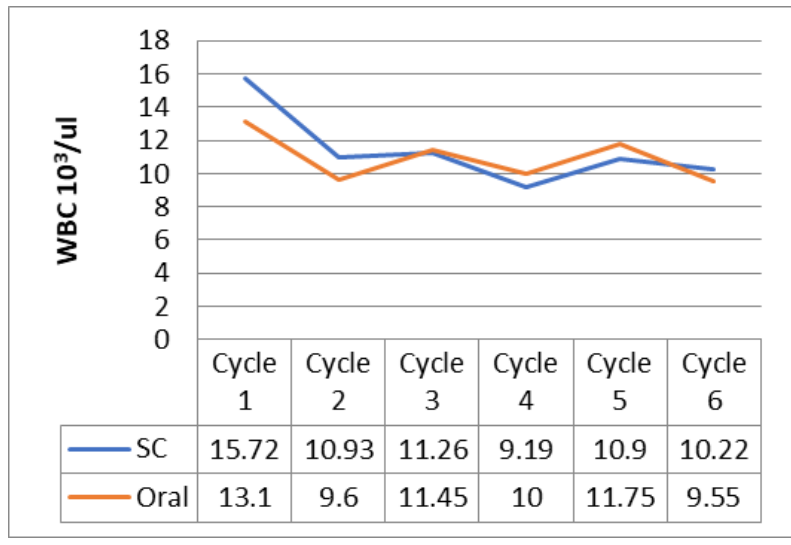

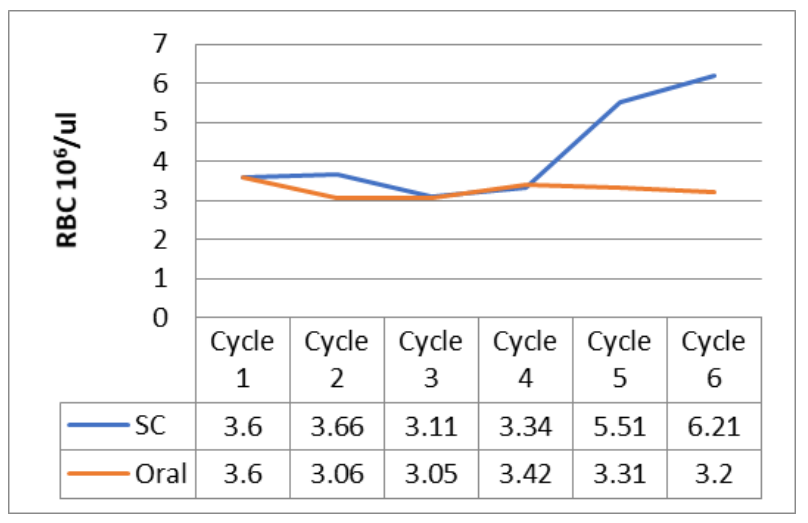



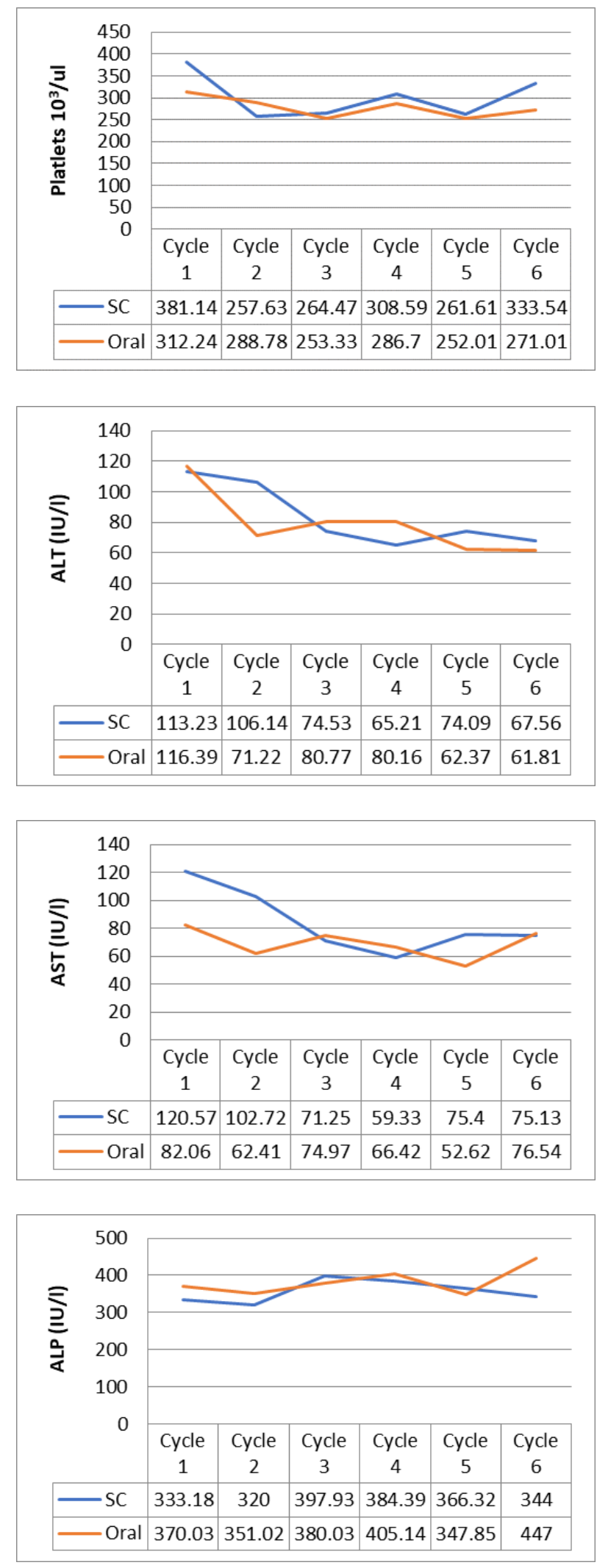
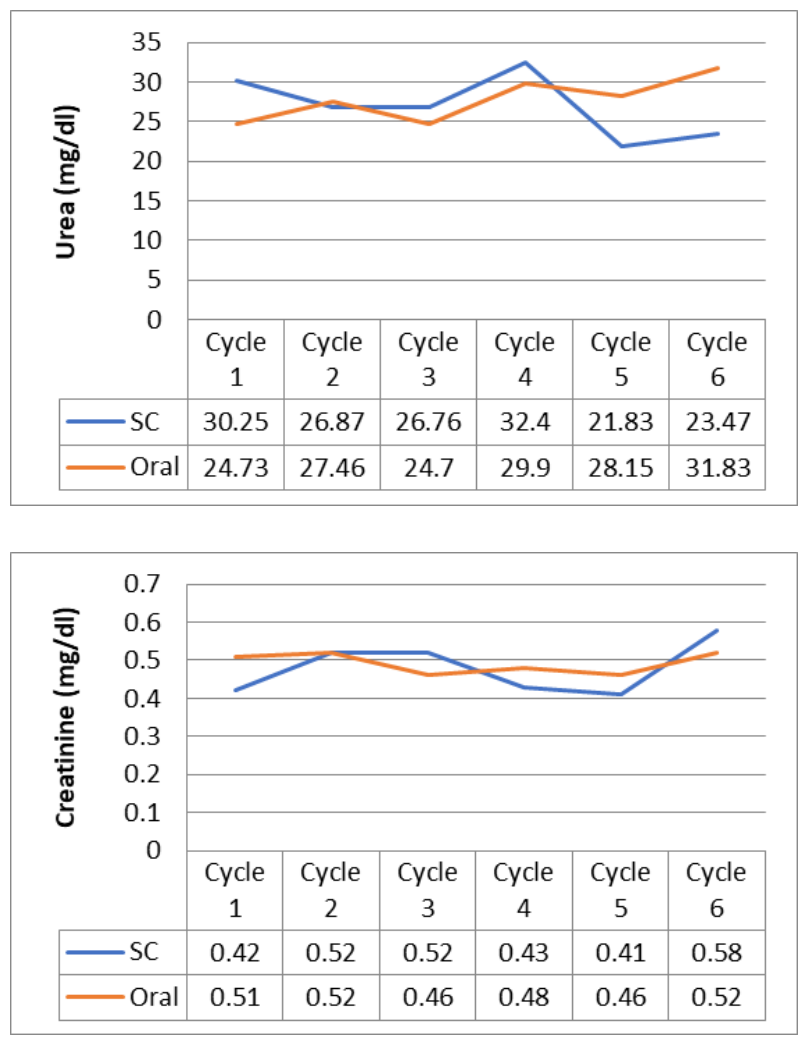

Figure 1: Comparison of clinical parameters of DFO and DFX

\section{DISCUSSION}

This study was conducted to compare the safety and efficacy of two iron chelators, DFO and DFX. Thalassemia is a major health and economic trouble in the Mediterranean region, with iron overload becoming major cause of mortality. Therefore, iron chelation is required to reduce the burden of iron with fewer side effects ${ }^{[23]}$. $\beta$ - thalassemia is very common in Pakistan and only few get bone marrow transplantation as treatment ${ }^{[24]}$.

In our study, proportion of male was high. This finding was observed in other studies as well [25-27]. Based on our literature review, previously available limited data shows that thalassemia is prevalent in rural areas as compared to urban ${ }^{[28-30]}$. Our study reported the same results. Previous studies showed that consanguineous marriage is major risk of hereditary diseases ${ }^{[30}$, 31]. It was also observed in this study that more than half of participants have thalassemia in their family history.

As in previous studies [32], this study also revealed that changes in serum ferritin concentration was similar for DFO and DFX. Both are effective in reducing serum ferritin level ${ }^{[33-35] .}$

In terms of safety profile, DFO and DFX showed same results. Consistent with the findings from previous studies ${ }^{[32,35-38]}$ it was observed from laboratory parameter that both treatments are safe. 
Our study did not report any serious adverse effects to either drug. DFO and DFX showed difference in RBCs and blood urea level, but the levels were within clinically accepted range. Serum creatinine, serum transaminases (ALT, AST, and ALP), WBCs, and platelets counts were same. Therefore, both treatments have same safety profile. In terms of comparable efficacy and safety of DFO and DFX, studies [39-41] identified that oral preparation are more compliant and convenient to be taken on long term basis.

\section{CONCLUSION}

In conclusion, we found that both DFO and DFX treatment are safe and effective in beta thalassemic patients. The oral DFX is suggested due to its more compliance and convenience.

\section{Conflict of Interest}

Authors do not have any conflict of interest

\section{Grants}

Research project did not receive any grant from governmental or non-governmental organizations

\section{Acknowledgements}

Authors acknowledge the contributions of all the participants.

\section{Authors Contributions}

Narjis Batool, collected the data, assisted in preparation of the manuscript and interpretations of the factual materials.

Sadia Yasmeen, collected the data and coordinated the activities on this project and helped in the analysis of the results.

Rabia Anwar, collected the data and coordinated the activities on this project and helped in the analysis of the results.

Zikria Saleem, is the head of the project. He organized the team for the smooth running of this project by coordinating all the members.

\section{REFERENCES}

1. Kelly N. Thalassemia. Pediatr rev. 2012; 33(9):434-5.

2. Weatherall DJ. Hemoglobinopathies worldwide: present and future. Current molecular medicine. 2008; 8(7):592-9.

3. Rehman A. Beta thalassemia prevention and Pakistan. Pak Paed J. 2011; 35(2):55-62.

4. Neufeld EJ. Update on iron chelators in thalassemia. Hematology 2010, Am Soc Hematol Educ Program. 2010; 2010(1):451-5.

5. Cappellini M-D, Cohen A, Porter J, Taher A, Viprakasit V. Guidelines for the management of transfusion dependent thalassaemia (TDT): Thalassaemia International Federation Nicosia, Cyprus; 2014.

6. Vitrano A, Sacco M, Rosso R, et al. Longitudinal changes in LIC and other parameters in patients receiving different chelation regimens: Data from LICNET. Eur. J. Haematol. 2018; 100(2):124-30.
7. Di Maggio R, Maggio A. The new era of chelation treatments: effectiveness and safety of 10 different regimens for controlling iron overloading in thalassaemia major. Br. J. Haematol. 2017; 178(5):676-88.

8. Barry M, Flynn DM, Letsky EA, Risdon R. Long-term chelation therapy in thalassaemia major: effect on liver iron concentration, liver histology, and clinical progress. Br Med J. 1974; 2(5909):1620.

9. Propper RD, Shurin SB, Nathan DG. Reassessment of the use of desferrioxamine B in iron overload. N Engl J Med. 1976; 294(26):1421-3.

10. Propper RD, Cooper B, Rufo RR, et al. Continuous subcutaneous administration of deferoxamine in patients with iron overload. $\mathrm{N}$ Engl J Med. 1977; 297(8):418-23.

11. Gabutti V, Piga A. Results of long-term iron-chelating therapy. Acta Haematolo. 1996; 95(1):26-36.

12. Brittenham GM. Development of iron-chelating agents for clinical use [editorial; comment]. 1992.

13. Alpendurada F, Smith GC, Carpenter J-P, et al. Effects of combined deferiprone with deferoxamine on right ventricular function in thalassaemia major. J Cardiovasc Magn Reson. 2012; 14(1):1-10.

14. Cappellini MD, Bejaoui M, Agaoglu L, et al. Prospective evaluation of patient-reported outcomes during treatment with deferasirox or deferoxamine for iron overload in patients with $\beta$-thalassemia. Clin ther. 2007; 29(5):909-17.

15. Cohen A. Management of iron overload in the pediatric patient. Hematolo. Oncol. clin. North Am. 1987; 1(3):521-44.

16. Arboretti R, Tognoni G, Alberti D. Pharmacosurveillance and quality of care of thalassaemic patients. Eur. J. Clin Pharmacol. 2001; 56(12):915-22.

17. Cappellini MD, Cohen A, Piga A, et al. A phase 3 study of deferasirox (ICL670), a once-daily oral iron chelator, in patients with $\beta$-thalassemia. Blood. 2006; 107(9):3455-62.

18. Dubey A, Sudha S, Parakh A. Deferasirox: the new oral iron chelator. Indian pediatr. 2007; 44(8):603-7.

19. Viprakasit V, Lee-Lee C, Chong QT, Lin K-H, Khuhapinant A. Iron chelation therapy in the management of thalassemia: the Asian perspectives. Int. J. hematol. 2009; 90(4):435-45.

20. Chang HH, Lu MY, Liao YM, et al. Improved efficacy and tolerability of oral deferasirox by twice-daily dosing for patients with transfusion-dependent $\beta$-thalassemia. Pediatr Blood Cancer. 2011; 56(3):420-4.

21. Elalfy MS, Adly AM, Wali Y, Tony S, Samir A, Elhenawy YI. Efficacy and safety of a novel combination of two oral chelators deferasirox/deferiprone over deferoxamine/deferiprone in severely iron overloaded young beta thalassemia major patients. Eur J Haematol. 2015; 95(5):411-20.

22. Kotrlik J, Higgins C. Organizational research: Determining appropriate sample size in survey research appropriate sample size in survey research. Information technology, learning, and performance journal. 2001; 19(1):43.

23. Ware $\mathrm{H}$, Kwiatkowski J. Optimal use of iron chelators in pediatric patients. Clin Adv Hematol Oncol. 2013; 11(7):433-41.

24. Lodhi Y. Economics of thalassemia management in Pakistan. Thalassemia awareness week. 2003.

25. Yagnik H. Post counselling follow-up of thalassemia in high risk communities. scientist. 1997; 34.

26. Sur D, Chakraborty A, Mukhopadhyay S. Dr. PC Sen Memorial Award Paper. A study of HIV infection in thalassaemia patients of rural Bengal. Indian J public health. 1998; 42(3):81-7.

27. Talsania S, Talsania N, Nayak H. A cross sectional study of thalassemia in Ahmedabad City, Gujarat, (Hospital based). Healthline, Journal of Indian Association of Preventive and Social Medicine. 2011; 2(1):48-51.

28. Dolai TK, Dutta S, Bhattacharyya M, Ghosh MK. Prevalence of hemoglobinopathies in rural Bengal, India. Hemoglobin. 2012; 
36(1):57-63.

29. Shahzad A, Rafiq N, Ullah I, Asad MJ, Ahmad MS, Waheed U. Knowledge, attitude and practices (KAP) of the families of $\beta$ thalassaemia children in thalassaemia centers of Rawalpindi and Islamabad, Pakistan. Blood transfus. 2017; 92:22.4.

30. Ahmed N, Khan BA, Bukhari SW, Khan KS, Sabir T, Nazir M. Knowledge, attitude and practices (KAP) of The families of Bthalassemia patients in a thalassemia Center of Karachi. Int J Curr Med Pharm Res. 2020; 6:4972-6.

31. Anwar S, Taslem Mourosi J, Arafat Y, Hosen MJ. Genetic and reproductive consequences of consanguineous marriage in Bangladesh. PloS one. 2020; 15(11):e0241610.

32. Hassan MAM, Tolba OA. Iron chelation monotherapy in transfusion-dependent beta-thalassemia major patients: a comparative study of deferasirox and deferoxamine. Electronic physician. 2016; 8(5):2425.

33. Cappellini MD. Long-term efficacy and safety of deferasirox. Blood rev. 2008; 22:S35-S41.

34. Moukalled NM, Bou-Fakhredin R, Taher AT. Deferasirox: over a decade of experience in thalassemia. Mediterr $\mathrm{J}$ Hematol Infect Dis. 2018; 10(1).

35. Anwar T. Efficacy and Safety of Intensive Desferal [Deferoxamine] Infusion in Thalassemia associated Iron Overload. Ann Pak Inst Med Sci. 2013; 9(4):195-7.

36. Arandi N, Haghpanah S, Safaei S, et al. Combination therapydeferasirox and deferoxamine-in thalassemia major patients in emerging countries with limited resources. Transfus Med. 2015; 25(1):8-12.

37. Ehlers KH, Giardina PJ, Lesser ML, Engle MA, Hilgartner MW. Prolonged survival in patients with beta-thalassemia major treated with deferoxamine. J pediatr. 1991; 118(4):540-5.

38. Ejaz MS, Baloch S, Arif F. Efficacy and adverse effects of oral chelating therapy (deferasirox) in multi-transfused Pakistani children with $\beta$-thalassemia major. Pak J Med Sci. 2015; 31(3):621.

39. Dou H, Qin Y, Chen G, Zhao Y. Effectiveness and safety of deferasirox in thalassemia with iron overload: a meta-analysis. Acta haematolo. 2019; 141(1):32-42.

40. Lal A, Porter J, Sweeters N, et al. Combined chelation therapy with deferasirox and deferoxamine in thalassemia. Blood Cells. Mol. Dis. 2013; 50(2):99-104.

41. Porter JB. Optimizing iron chelation strategies in $\beta$-thalassaemia major. Blood rev. 2009; 23:S3-S7. 